\title{
Interaction analysis of urban space and transportation in Baoding City
}

\author{
Rui Wang ${ }^{1, a, *}, J u n$ Yin $^{1, b}$ and Ning Wang ${ }^{1, \mathrm{c}}$ \\ ${ }^{1}$ College of urban and rural construction,Agricultural University of Hebei , HeBei 071000, China. \\ a1229490566@qq.com, ${ }^{\text {b } 1542248561 @ q q . c o m, ~}{ }^{c}$ wn58@163.com
}

Keywords: Baoding, Urban Space, Traffic, Interactive Influence, Urban Vitality

\begin{abstract}
In order to coordinate the interaction between urban space and traffic of Baoding, and enhance the city vitality, improve the functions of the city space, alleviate traffic congestion, give full play to the functions of the city, then adapt to the coordinated development of Beijing, Tianjin and Hebei better. This paper divides the development course of urban space and traffic in Baoding into five stages, and analyzes the interaction and interaction mechanism of urban space and traffic in each stage. Then come to the conclusion: In different periods, the relationship between urban space and transportation is different, and both of them are constantly adapting and coordinating with each other in the process of urban development. Then, the paper expounds the present situation of urban space and traffic in Baoding, points out the existing problems between them, then on this basis, getting the coordinated development strategy of urban space and traffic in Baoding, and to increase urban vitality and improve urban competitiveness.
\end{abstract}

\section{Introduction}

In different periods, the interaction between urban space and traffic in Baoding is different. at the present stage, the urban space in Baoding has developed disorderly, functional space scattered, green ecological space degradation and so on; the width of traffic road is increasing, urban congestion problems can not be alleviated, but the problem of urban congestion is not alleviated. In 2015, the advance of the coordinated development of Beijing, Tianjin and Hebei and the planning of "Xiong'an New Area" have put forward higher requirements for the development of urban space and traffic in Baoding. The urban space of Baoding is expanding to east and north, and the new urban space is dispersed. But there is no corresponding development of urban traffic, and causes the phenomenon of urban space guides the development of traffic. However, most studies show that urban transportation leads to space development, and only traffic accessibility is high, people are active, and urban space will have vitality.[1] At the present stage, the coordination of urban space development and traffic development in Baoding are not reasonable, and urban space development is prior to traffic development. Therefore, it is particularly important to seek the coordination mechanism of urban space and traffic in Baoding, and put forward the optimization proposals to meet the needs of people's life and increase the vitality of the city.

\section{The evolution process of urban space and urban traffic in Baoding}

As a whole, urban space in Baoding has expanded in all directions, and the urban traffic has developed rapidly. Firstly, because of the geographical position, traffic and other factors, the development direction and expansion degree of urban space are different in different periods. As a result, urban space mainly developed eastward, northward and westward. Although urban space also expanded southward, but the extended area was relatively small. Urban traffic system is also developing and improving, such as the development of road network has changed from "grid road" network into "the Annular road network + Radioactive road network", single traffic has gradually evolved into various transportation, the dominant traffic mode has changed from carriages 
and walks to cars and buses. Taking a broad view of the historical evolution of urban space and traffic in Baoding, it can be divided into the following stages:

\subsection{The first stage: the Qing Dynasty - 1949}

During the Qing Dynasty, the construction area of Baoding was about 3 square kilometers, with population of about 60 thousand. The standard grid road network in the city was narrow and the streets were 6 or 7 meters wide. With the completion of the Luhan railway in 1899, Baoding's outbound traffic became railways and waterways, and the city expanded westward and southward. The urban expansion speed was slower because the mode of transportation(such as carriage, walking and rickshaw) reached a shorter distance within a certain period of time at that time. After the railway station was built, the new roads were built from rail station to urban area, and make transportation convenient, then traffic pattern had changed too.

\subsection{The second stage: 1949 - 1959}

Baoding had a good geographical position. NanGuan wharf accessed to Tianjin, Shanghai, Suzhou and other places. And the rail station facilitated the link with Beijing. Due to the limitation of the train transportation, the urban space didn't develop around the railway station, but rather mainly developed around the South Wharf and formed the commercial and trade center. There has been no dramatic change in the city's internal traffic. Until to 1953, the country implemented the "the first five years" plan, and the government of Baoding established some factories in the Western Suburbs. At that time, the form of the road network was mainly grid, and three broad roads were built to connected industry and residential space. The main modes of transportation were walking and cycling.[2] But the far distance between the factory and the residence promoted the generation of buses.

\subsection{The third stage: 1960 - 1978}

In this period, because of Great Chinese Famine and some political factors, urban space expanded slowly. From 1963 to 1983,The built-up area increased from 37 square kilometers to 43 square kilometers, the growth area is very small in twenty years. During this period, urban traffic continued to develop, and the western industry continued to develop. In order to facilitate the transportation of goods, the railway lines in the city began to build. Several trunk roads have been built to facilitate the traffic between the east and the west. And the density of the road is increasing.

\subsection{The fourth stage: 1979 - 2002}

During this period, urban space developed into an inward filling period. The reform of the economic system made the service industry develop rapidly, and the urbanization speed up. The space model that "west of industry, east of residence" made most of the business layout in the regions that having convenient transportation and surrounding the residential area. With the development of the western industries and the establishment of the supporting facilities, the urban center had shifted westward. In the late 1880s, our country implemented the policy that pay for using the land, and the land price in downtown increased. The urban function structure changed and the city extended to the outside. Urban transportation: the main roads crisscrossed, the density of roads increased, and the traffic connecting the East and West was convenient.

\subsection{The fifth stage: 2002 - up to now}

At the beginning of the twenty-first Century, urban space of Baoding developed mainly northward, and developed moderately southward and eastward, and developed to the West optimally.[3] All the functional spaces were constantly improved. In 2015, the development strategy about Beijing, Tianjin and Hebei develop coordinately was put forward formally. The establishment of high-speed rail station in the east of Baoding and the opening of some high-speed rail lines made the urban space develop rapidly eastward. With the expansion of the city in all directions, the density of urban roads is also constantly improving and urban roads continue to develop eastwards. In short, urban space and urban traffic interact with each other. 


\subsection{Conclusion}

In different periods, the relationship between urban space and traffic development in Baoding is different. The specific relationship is shown in Table 1 . The evolution of urban spatial morphology at different times in Baoding is shown in Figure 1.

Table 1 The relationship between urban space and traffic development in Baoding

\begin{tabular}{|c|c|c|c|c|c|c|}
\hline Date & $\begin{array}{c}\text { Urban } \\
\text { area }\end{array}$ & $\begin{array}{c}\text { Urban } \\
\text { Population }\end{array}$ & $\begin{array}{c}\text { Mode of } \\
\text { transportation }\end{array}$ & $\begin{array}{c}\text { Road network } \\
\text { structure }\end{array}$ & $\begin{array}{c}\text { Urban spatial } \\
\text { development } \\
\text { direction }\end{array}$ & $\begin{array}{c}\text { Relationship } \\
\text { between urban space } \\
\text { and traffic }\end{array}$ \\
\hline $\begin{array}{c}\text { Late of } \\
\text { Qing } \\
\text { Dynasty }\end{array}$ & 3 & 6 & $\begin{array}{c}\text { Walk, } \\
\text { Carriage }\end{array}$ & $\begin{array}{c}\text { Grid Road } \\
\text { Network }\end{array}$ & ------ & Space Development \\
\hline 1949 & ------ & ------ & Walk, Bike & $\begin{array}{c}\text { Grid Road } \\
\text { Network }\end{array}$ & $\begin{array}{c}\text { Development } \\
\text { to Southward }\end{array}$ & $\begin{array}{c}\text { Traffic Leading } \\
\text { Space Development }\end{array}$ \\
\hline 1963 & 37 & 31.5 & $\begin{array}{c}\text { Walk, Bike, } \\
\text { Bus }\end{array}$ & $\begin{array}{c}\text { Grid + } \\
\text { Radioactive Road } \\
\text { Network }\end{array}$ & $\begin{array}{c}\text { Development } \\
\text { to Westward }\end{array}$ & $\begin{array}{c}\text { Space Leading } \\
\text { Traffic Development }\end{array}$ \\
\hline 1983 & 43 & 40.7 & $\begin{array}{c}\text { Walk, Bike, } \\
\text { Bus,Car }\end{array}$ & $\begin{array}{c}\text { Grid + } \\
\text { Radioactive Road } \\
\text { Network }\end{array}$ & $\begin{array}{c}\text { Inward Filling } \\
\text { Development }\end{array}$ & $\begin{array}{c}\text { Traffic Leading } \\
\text { Space Development }\end{array}$ \\
\hline 1998 & 63.5 & 61 & $\begin{array}{c}\text { Walk, Bike, } \\
\text { Bus,Car }\end{array}$ & $\begin{array}{c}\text { Grid + Ring Road } \\
\text { Network }\end{array}$ & $\begin{array}{c}\text { Inward Filling } \\
\text { Development }\end{array}$ & $\begin{array}{c}\text { Traffic Leading } \\
\text { Space Development }\end{array}$ \\
\hline 2008 & 129.0 & 105.53 & $\begin{array}{c}\text { Walk, Bike, } \\
\text { Bus,Car }\end{array}$ & $\begin{array}{c}\text { Grid + Ring Road } \\
\text { Network } \\
\text { Develop to } \\
\text { Northward, } \\
\text { East and } \\
\text { South }\end{array}$ & $\begin{array}{c}\text { Traffic Leading } \\
\text { Space Development }\end{array}$ & \\
\hline 2014 & 146.03 & 110.45 & $\begin{array}{c}\text { Walk, Bike, } \\
\text { Bus,Car }\end{array}$ & $\begin{array}{c}\text { Grid + Ring Road } \\
\text { Network }\end{array}$ & $\begin{array}{c}\text { Develop to } \\
\text { Northward } \\
\text { and East }\end{array}$ & $\begin{array}{c}\text { Space Leading } \\
\text { Traffic Development }\end{array}$ \\
\hline
\end{tabular}

Mark: Area Measurement Unit: square Kilometers; Population Measurement Unit: 10,000 persons

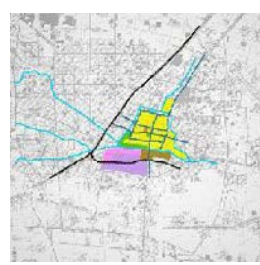

Date:1949

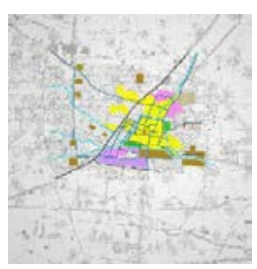

Date:1956

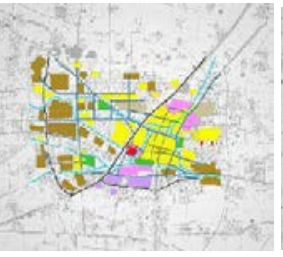

Date:1963

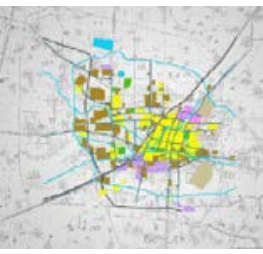

Date:1983

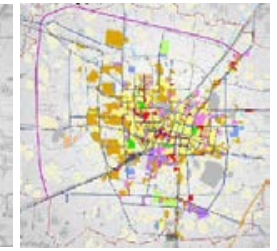

Date:2008

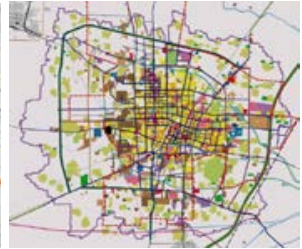

Date:2014

Fig.1 The evolution of urban spatial morphology at different times in Baoding

\section{Analysis the influences of urban space and urban traffic and the existing problems}

\subsection{The influences of urban space on urban traffic}

One:The change of urban space affects the layout of urban traffic

Different urban spatial patterns correspond to different transportation network models.[4] When Urban space develops like blocks , the form of transportation layout generally adopt "grid road" or "grid road + radioactive road network". If a city like belt, the form of transportation layout generally adopt "axial road network + radioactive road network". A multi-center city's form of transportation layout generally adopt "reticular road network + radioactive road network".

Two:Urban development intensity affects urban traffic

Low intensity of urban development leads to less passenger in the center of the city, which not conducive to the improvement of public transport, but to promote the use of private cars. If the intensity of urban development is large and the density is high, then the population will be large. At first, in order to ease the connection, a large number of private cars is used, and then it causes urban 
congestion. But it will eventually stimulate the development of urban public transport, and then reduce costs, alleviate urban problems and reduce environmental pollution.

\subsection{The influences of urban traffic on urban space}

On the one hand, urban traffic have an effect on urban spatial form.Traffic has gone through walking, horse drawn carriage, bicycle, bus, car, etc. The urban spatial form has also changed gradually. During the walking and carriage periods, the speed was slower, the range of arrival is smaller within a certain time. Urban space developed like blocks. Bicycle and bus age, moderate speed, suitable for medium and long distance trips. Urban space also began to extend to the surrounding area, showing the development of single-center or development by leaps and bounds. Bus and car period, urban roads continue to broaden and extend, and urban space accessibility is further improved. Urban space mainly begins to multi-core development.

On the other hand, urban transportation guides the layout of urban space.The accessibility of urban traffic has a direct impact on the accessibility of urban space. Land exploitation and the service facilities for residents to live and produce are spread along the traffic routes, forming different functional spaces. With the development and perfection of the transportation system, the urban function space is also expanding and improving.[5]

\subsection{The problems of urban traffic and urban space in Baoding}

One:The current situation and existing problems of traffic in Baoding

By 2016, the length of the road in central district of Baoding is 459.5 kilometers, the density of the urban road network is $3.28 \mathrm{~km} / \mathrm{km}^{2}$, and the backbone network skeleton of "six vertical, six horizontal and one ring" has been basically formed, but the secondary road and branch road network structure needs to be further improved. The road network construction in Baoding can reference to table 2. The number of motor vehicle ownership in central city of Baoding is 582 thousand, the operating public traffic are 1673 units, and the motor vehicle for public traffic per 10000 persons is 14.9 standard units. The corridor of public transport has been distributed on a large scale and in a network, but the lack of support by large capacity system is difficult to meet the needs of the passenger flow in the central city.

With the rapid development of economy and the improvement of people's living standard, the number of private cars is increasing. However, the low level of road surface area per capita and low density of urban roads can not meet the crowded traffic. The parking facilities are not perfect, and the phenomenon of roadside parking is very general, which make the roads crowded. The public transport system is not perfect, and it can not meet the requirements of people for convenient traffic.

Table 2 The relationship between urban space and traffic development in Baoding

\begin{tabular}{|c|c|c|c|c|c|}
\hline $\begin{array}{c}\text { Total length of } \\
\text { urban roads } \\
(\mathrm{km})\end{array}$ & $\begin{array}{c}\text { Length of } \\
\text { Expressway } \\
(\mathrm{km})\end{array}$ & $\begin{array}{c}\text { Length of } \\
\text { main road } \\
(\mathrm{km})\end{array}$ & $\begin{array}{c}\text { Length of secondary } \\
\text { main road } \\
(\mathrm{km})\end{array}$ & $\begin{array}{c}\text { Length of } \\
\text { branch road } \\
(\mathrm{km})\end{array}$ & $\begin{array}{c}\text { the density of the } \\
\text { urban road network } \\
(\mathrm{km} / \mathrm{km} 2)\end{array}$ \\
\hline 459.5 & 69.2 & 156.7 & 120.4 & 113.2 & 3.28 \\
\hline
\end{tabular}

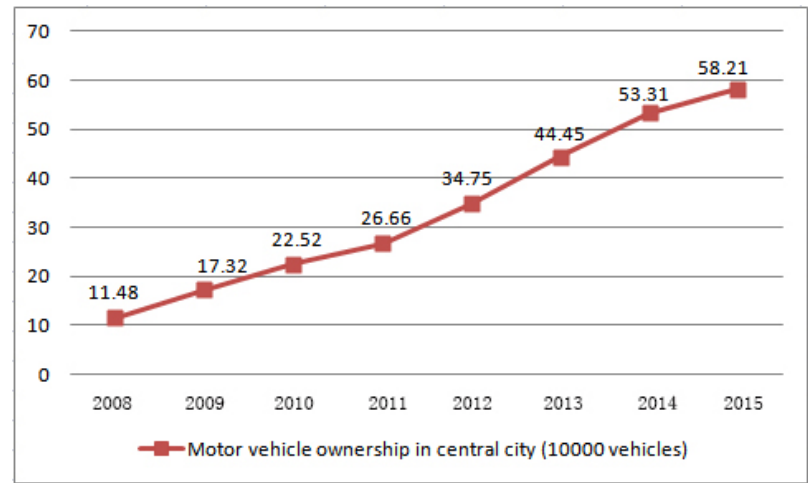

Fig.2 The changes of motor vehicle ownership in Baoding 
Two:The present situation and existing problems of urban space in Baoding

In 2015, the State Council approved the application of changing the New District to JingXiu District meanwhile the South District and the North District to LianChi District, and changing Mancheng County/Qingyuan County/Xushui County to Mancheng District/Qingyuan District/Xushui District. Since then, the administrative divisions of Baoding are divided into 5 districts, 15 counties and 4 county-level cities from the pattern of 3 districts, 18 counties and 4 county-level cities. [6]

By the influence of the coordinated development of Beijing, Tianjin and HeBei and the impact of the planning of "Xiong' an New Area", the urban space of Baoding continues to develop to north and east. The built-up area continues to expand, the land value continues to rise, the land use intensity increases unceasingly, the density of buildings increase constantly, the mixing degree of each functional space is not high, and lead to the commuting time of cities is longer. Now, space expansion is guided by policy to a great extent and urban space development guides traffic development.

\subsection{Summary}

Urban traffic and urban space interact with each other. The development of urban traffic affects the accessibility of urban space, which leads the change of land use mode and land value, and results in the change of urban function layout, and finally affects urban space.[7]In turn, the expansion of urban space and the adjustment of internal structure also affect the distribution of traffic demand space, and affect the layout of urban traffic.

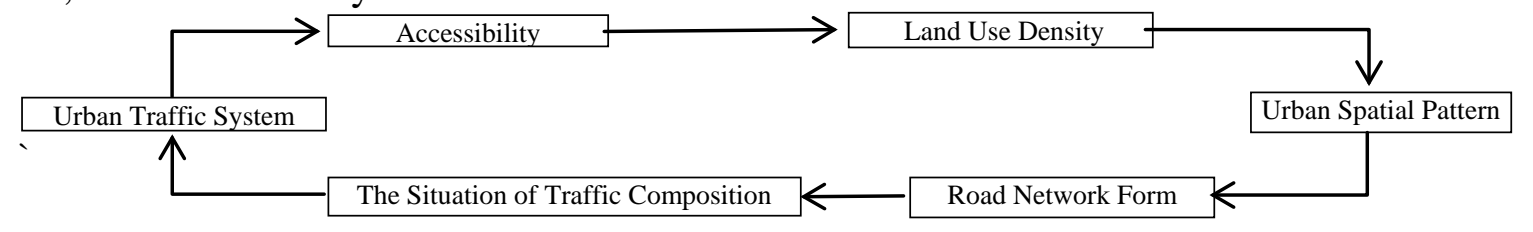

Fig.3 The interaction between Urban traffic and urban spatial.

\section{The optimization strategies of urban space and urban traffic}

\subsection{Coordinate urban transportation planning, urban land planning and urban planning}

Urban transportation planning, urban land planning and urban planning restrict each other and link to each other. The old ideas of planning should be abandoned at the present stage of urban development, and new planning concepts should be established. Making urban transportation planning, land planning and urban planning coordinate, to ensure that each plan is integrated under the consistent organization, and to link up the different planning levels accurately, then to form a planning system of taking spatial organization as the core and coordinating various plans, and finally to solve the city problem.

\subsection{Disperse the functions of central city, promote the urban space to multi-core}

We should make clear the main functions of the central city of Baoding and the connections and strengthen ties among the central city, Qingyuan, Xushui, Mancheng and Xiong'an New Area. Relying on the competitive industries to gather the urban resources, and to form a new urban growth pole. Baoding can rely on its excellent industries such as automobile manufacturing, new energy manufacturing, textile and other industries. And form the multi-core spatial pattern of "The south is the automobile industry, the new energy in the north, the textile industry in the East and the West is the preserve of nature" . In the process of forming a multi-core spatial pattern, the balance of land use should be taken into account, and pay attention to the development of the surrounding city. [8]The surrounding areas of the city should contact with the main urban areas, and offer help to evacuate the population and function of the central city, and relieve traffic pressure, then finally make urban transportation and urban space develop harmoniously. 


\subsection{Change the thought, improve transport facilities, coordinate dynamic and static traffic}

Urban traffic is in a period of rapid development and change. Urban traffic needs to seek some changes in planning concepts/development constraints/planning perspectives/technical means and so on, and seek norms in the changes, then effectively guide the planning.[9]

According to the different characteristics and needs of each city, we can provide an organic combination of various transportation modes, then strive to achieve good results timely, and to protect the overall urban traffic. According to the different needs of travelers, different travel plans are provided, and different traffic modes are seamlessly linked up.[10] The establishment of this system requires the government, social organizations and enterprises to participate in cooperation.

\subsection{The development of space should be guided by public transportation}

Transport oriented development is a dense residential lifestyle that integrating public transport with shopping, dining and entertainment. It provides comfortable conditions for residents, such as walking distances, excellent views, the place close to service facilities and other exciting elements of city life. [11]Finally, creating a rich community life and increasing urban energy and attraction.

\section{Conclusion}

In different stages of urban development, urban transportation and urban space are constantly changing, and they are related to each other closely. Now Baoding is in a period of dramatic changes in internal and external environment, therefore, it is important to deal with the relationship between urban space and traffic development. In terms of transportation, road design should be people-oriented, the density of road network should be increased, especially the density of secondary roads and branch road. And a one-way drive should be provided on the narrow width of the road to reduce the vehicle and relieve traffic congestion. Establish a high frequency, direct type of fast and convenient public transport system between the central city and Mancheng District/Qingyuan District/Xushui District/Xiong'an New Area. Urban space development should encourage the mixed use of residential and service functions, the housing/the workplace/business/park space and other functional space should be linked organically to reduce traffic costs. In addition, urban spatial density is closely related to urban traffic development, if the urban space can be closely linked with the public transport, it can not only save urban land, but also effectively shorten the distance and save time cost.The new urban construction should be closely linked with the built-up area and reach the balance of work and living within the short commute distance. Only in this way can ensure a long-term, healthy and orderly development of the city.

\section{References}

[1] JingYuan Zhao, Analysis of the interaction between urban traffic and urban spatial structure in Tianjin,2012.

[2] ChenRui Yang, Some thoughts on the relationship between urban development and transportation infrastructure construction, 2014.

[3] Information on http://m.9512.net/read/d18f6f8617a475732d56e55e.ht

[4]Hong Zhu, Study on the planning of urban community public sports facilities based on the idea of low carbon travel, 2013.

[5] Yuan Zhang, International experience and Inspiration of urban traffic development, 2013.

[6] Information on https://baike.so.com/doc/24056800-24639931.html

[7]YanXia Zhao, Study on the interaction between urban spatial structure and urban transportation system in Ji'nan, 2015.

[8] Bei Xu, Study on urban traffic problems in Lanzhou, 2016.

[9] JinMan Xu, How to use urban planning to solve urban traffic problems, 2014. 
[10]Yong Jia, The future trend of urban development: "microcirculation", 2012.

[11] John Lund Kriken, Philp Enquist and Richard Rapaport: Nine Planning Principles for the Twenty-First Century(2013). 